\title{
Pendekatan Model Discovery Learning dalam Keterampilan Teknik Shooting Permainan Bola Basket
}

\author{
Ali Munir \\ Program Studi Pendidikan Jasmani, Kesehatan, dan Rekreasi, STKIP Modern Ngawi, \\ aliimuniir99@gmail.com \\ Arief Nur Wahyudi \\ Program Studi Pendidikan Jasmani, Kesehatan, dan Rekreasi, STKIP Modern Ngawi, \\ ariefnurwahyudi29@gmail.com \\ Aba Sandi Prayoga \\ Program Studi Pendidikan Jasmani, Kesehatan, dan Rekreasi, STKIP Modern Ngawi, \\ adamhamis78@gmail.com
}

\begin{abstract}
Abstrak
Belajar mengajar merupakan salah satu tujuan dari undang-undang dasar 1945 yang tercantum pada alinea ke-4 yakni "Mencerdaskan Kehidupan bangsa" di mana sebuah pembelajaran ini sangat penting bahkan menjadi suatu landasan dari undang-undang nomor 20 tahun 2003 yang terdapat pada pasal 1 ayat (18) dengan tercantumnya pengertian Wajib Belajar. Akan tetapi hasil daripada observasi di beberapa sekolah swasta maupun negeri ini masih banyak kurangnya interaksi yang baik antara guru dengan siswa karena faktor dari media/model pembelajaran bola basket yang monoton dan sarana prasarana yang sangat minim. Metode penelitian ini menggunakan metode penelitian deskriptif kualitatif. Sehingga dengan adanya model pembelajaran berbasis discovery learning ini dapat membantu siswa untuk berperan aktif mencari edukasi ideide yang kreatif dan menarik di dalam permaian bola basket serta dapat membuat sumber pembelajaran yang tidak membosankan dikala sarana prasarana yang minim, seperti memadukan antara teknik shooting dengan nama-nama hewan serta membantu siswa untuk meningkatkan keterampilan teknik shooting dalam permainan bola basket.
\end{abstract}

Kata Kunci: bola basket, discovery learning, teknik shooting

\section{PENDAHULUAN}

Pendidikan jasmani adalah suatu proses pembelajaran melalui aktivitas jasmani yang didesain untuk meningkatkan kebugaran jasmani, mengembangkan keterampilan motorik, pengetahuan dan perilaku hidup sehat. Lingkungan belajar diatur secara seksama untuk meningkatkan pertumbuhan dan perkembangan seluruh ranah, yakni ranah psikomotor, kognitif, dan afektif pada setiap siswa.

Peran guru itu sendiri adalah sebagai fasilitator bukan untuk sebagai sumber belajar, Akan tetapi masih banyak siswa yang belum mengetahui akan apa arti pendidikan jasmani yang sebenanya, siswa hanya mengetahui bahwa pendidikan jasmani(penjas) hanya sebagai ajang olah raga dan olah raga saja, padahal tujuan pendidikan jasmani itu sendiri mempunya banyak ranah positif yang terkandung didalamnya. Apalagi lagi guru yang sulit untuk memberikan pembelajaran karena faktor sarana dan prasarana yang belum mencukupi.

Selain itu Menurut Suryobroto (2004:8), tujuan dari pendidikan jasmani adalah untuk membentuk siswa agar mempunyai sikap/etika yang baik, kecerdasan, dan keterampilan (psikomotorik), sehingga peserta didik mempunya pemikiran yang dewasa dan mandiri, yang nantinya akan mereka gunakan di kehidupan sosial maupun dalam dalam 
kehidupan sehari-hari. Sehingga agar siswa lebih faham mengenai arti pembelajaran yang sebenarnya, di perlukan pendeketan-pendekatan dengan metode discovery learning ini. Menurut Bell (1978), beberapa tujuan spesifik dari pembelajaran model discovery learning ini, yakni sebagai berikut: 1) Dalam proses belajar mengajar siswa memiliki kesempatan untuk terlibat secara aktif dalam pembelajaran. Kenyataan menunjukkan bahwa banyak siswa yang berpartisipasi dalam pembelajaran meningkat ketika penemuan digunakan 2) Melalui pembelajaran dengan model tersebut, siswa belajar menemukan pola dalam situasi konkret maupun abstrak, dan juga siswa banyak meramalkan (extrapolate) informasi tambahan yang diberikan 3) Pembelajaran dengan penemuan tersebut membantu siswa untuk membentuk cara kerja bersama yang efektif, saling membagi informasi, serta mendengar dan menggunakan ide-ide orang lain. Tujuan daripada penelitian ini ialah siswa lebih memahami akan arti pendidikan dan seorang guru dapat memberikan edukasi kepada siswa agar dapat memiliki ide-ide yang kreatif dan inovatif untuk media pembelajaran di kala sarana dan prasarana yang sangat minim untuk di gunakan, sehingga siswa merasa tertarik dan aktif dalam mengikuti serangkaian proses belajar mengajar. Sebagaimana tercantum dalam undang-undang keolahragaan Nasional Menpora Nomor : 3 tahun 2005 dalam Bab XI pasal 3 dan 4 yang berbunyi sebagai berikut: "Jumlah dan jenis prasarana olahraga yang dibangun harus memperhatikan potensi keolahragaan yang berkembang di daerah setempat. Prasarana olahraga yang dibangun di daerah wajib memenuhi jumlah dan standar minimum yang ditetapkan oleh pemerintah".

Metode pembelajaran (discovery learning) ini ditokohi oleh Jerome Brunner. Dengan teorinya yang disebut Free Discovery Learning. Brunner mengatakan bahwa 'proses belajar akan berjalan dengan baik dan kreatif jika guru memberikan kesempatan kepada siswa untuk menemukan suatu konsep, teori, aturan, atau pemahaman melalui contoh-contoh yang ia jumpai dalam kehidupannya'. Dari model pembelajaran discovery learning ini sangat cocok untuk bapak/ibu guru dalam memberikan suatu materi yang dapat dipadukan, seperti ketampilan teknik shooting bola basket dengan nama-nama hewan seperti, : (1) hewan katak di mana cara memegang bola dengan posisi badan condong ke bawah (2) hewan kanguru dengan postur tubuh yang lebih condong ke depan dengan memegang bola seperti halnya hewan kanguru (3) dan terakhir hewan jerapah merupakan gerakan terakhir untuk melempar bola dengan tangan membentuk seperti hewan jerapah.

\section{METODE}

Pada tahapan penelitian ini menggunakan metode deskriptif kualitatif, Penelitian deskriptif kualitatif ini merupakan salah satu dari jenis penelitian yang mengungkapkan kejadian atau fakta, keadaan, fenomena, variabel dan keadaan yang terjadi saat penelitian berlangsung dengan menyuguhkan apa yang sebenarnya terjadi. Subjek pada penelitian ini berlangsung pada salah satu sekolah swasta yang berada di Kabupaten Ngawi, yakni di SMA Ma'arif Ngawi pada tahun pelajaran 2018/2019 yang berlangsung selama 1 tahun. Letak lokasi SMA Ma'arif itu sendiri sangat strategis karena dekat dengan area perkotaan. Objek daripada penelitian ini adalah untuk meningkatkan keterampilan teknik shooting bola basket pada siswa kelas X SMA Ma'arif Ngawi yang jumlah 41 siswa terdiri dari 29 laki-laki dan 12 perempuan dengan menggunakan model pembelajaran discovery learning.

Data dalam penelitian ini menggunakan sampel melalui tes dan kemampuan teknik shooting dalam bola basket yang disusun berdasarkan validitas isi. Tes tersebut terdiri dari beberapa 
komponen dasar teknik shooting bola basket dengan menggunakan 2 tangan, yaitu : (1) Postur tubuh dengan posisi tegak, pandangan mata menghadap ke arah gerakan bola dengan posisi kaki kanan di depan dan kaki kiri di belakang (2) Kedua lutut ditekuk $\pm 90^{\circ}$ (3) Bola dipegang dengan menggunakan kedua telapak tangan dan posisi jari-jari tangan terbuka (4) Arah pandangan mata ke ring basket yang akan dituju (5) Dorong bola basket ke arah ring sampai lengan dan lutut lurus sejajar (6) Posisi laju bola yag benar adalah seperti gerakan parabola atau melengkung (8) Akhir dari gerakan tersebut lengan lurus rileks dan arah pandangan mata mengikuti gerakan bola. Akan tetapi setelah mengikuti caoching clinic bola basket di Gedung Olah Raga Kediri, yang dihadiri oleh ribuan guru serta coach terkenal yaitu Coach Carlos Barroca dapat disimpulkan bahwa teknik shooting tersebut dapat dirangkum hanya dengan 3 komponen dasar yang dapat di padukan dengan nama-nama hewan seperti, : Katak, Kanguru, dan Jerapah. Maka dari itu guru dapat menerapkan metode discovery learning tersebut kepada siswa agar siswa senang, dan ikut serta aktif dalam pembelajaran tersebut, sehingga tidak terjadi pembelajaran yang monoton.

Isi tes tersebut adalah Tes yang membandingan antara skill shooting yang tertera pada pembelajaran dasar tersebut dengan skill shooting hasil dari discovery learning itu sendiri tanpa menggunakan alat dan bahan. Data tersebut ialah data yang dilakukan pada setiap proses observasi belajar mengajar dari kegiatan Penelitian Tindakan Kelas yang telah bekerja sama dengan Kepala Sekolah, WAKA Kurikulum, WAKA Kesiswaan, dan guru pengampu mata pelajaran penjaskes beserta peserta didik dengan jumlah 41 siswa dimana lama penelitian selama 2 bulan dengan alokasi waktu 1 minggu 1x pertemuan dengan durasi waktu 120 menit. Yang dianalisis secara deskriptif kualitatif menggunakan teknik persentase untuk melihat kecenderungan yang terjadi dalam kegiatan pembelajaran. Pada pengumpulan data itu sendiri Aspek-aspek penilaian tersebut antara lain, :

1. Hasil keterampilan shooting bola basket dengan menganalisis rata-rata presentase teknik gerakan-gerakan yang dikategorikan dalam pembelajaran discovery learning

2. Penilaian Kognitif peserta didik : dengan jawaban peserta didik atas pertanyaan yang telah diberikan guru.

\section{HASIL DAN PEMBAHASAN}

Dari hasil setiap penelitian yang di observasi pada bulan pertama mengacu pada teknik shooting dengan model pembelajaran demonstrasi dari sumber buku, pada hasil analisis tersebut siswa dominan susah untuk memahami model pembelajaran itu, selain itu dengan adanya model tersebut siswa lebih cenderung malas untuk memperhatikan proses guru memberikan demonstrasi teknik shooting bola basket karena faktor pembelajaran yang monoton apalagi jumlah sarana dan prasarana yang yang sangat sedikit dan kurang memadai sehingga sangat mempengaruhi proses belajar mengajar. Penelitian yang dilakukan selama 1 bulan mendapatkan hasil 25\% dari 41 siswa terdapat 10 siswa yang telah paham akan materi yang diberikan dan sisanya masih belum paham mengenai materi yang disampaikan.

Dengan adanya metode ini guru dapat meminimalisir waktu proses pembelajaran menggunakan teknik discovery learning, dengan cara memberikan materi yang mengombinasikan antara teknik shooting dengan cara menirukan gerakan hewan.

Pada bulan kedua digunakannya metode tersebut dengan cara :

1. Siswa dibariskan di lapangan secara vertical dan di bagi menjadi 4 saf dengan jarak 2 lengan tangan. 
2. Menginstruksikan kepada siswa untuk melakukan teknik shooting yang sebelumnya telah di ajarkan.

3. Memberikan edukasi hasil dari metode discovery learning tentang teknik shooting bola basket tersebut, antara lain, :

a. Pertama menggunakan gaya katak

1) Badan lebih condong ke bawah

2) Posisi lutut di tekut $\pm 90^{\circ}$

3) Kedua jari-jari tangan di renggangkan untuk memegang bola basket

b. Kedua gaya kanguru

1) Posisi badan lebih condong ke depan

2) Kedua tangan memegang bola layaknya seperti hewan kanguru, dengan posisi tangan kiri untuk menyangga bola dan sikut tangan kanan menekuk $\pm 90^{\circ}$ untuk mendorong bola

3) Pandangan fokus ke arah ring bola basket

c. Terakhir gaya jerapah

1) Postur badan tegak

2) Pandangan lurus kearah ring bola basket

3) Kedua kaki menyerupai posisi katak dan kanguru

4) Posisi akhir pada tangan kanan, mendorong bola menuju ring dengan akhiran pergelangan tangan menekuk seperti kepala hewan jerapah.

4. Mengujikan hasil praktik dari gerakan tersebut kepada siswa secara berulangulang tanpa menggunakan bola basket, sehingga mempermudah proses guru dalam melakukan pembelajaran.

5. Hasil uji praktik tersebut dilakukan secara rutin dengan rentan waktu $3 \mathrm{x}$ pertemuan setiap 1 minggu terdapat $1 \mathrm{x}$ pertemuan.
6. Di hari terkahir pada minggu ke-4 memberikan evaluasi terhadap siswa mengenai teknik shooting tersebut serta memberikan beberapa pertanyaanpertanyaan seputar pembelajaran mengenai teknik shooting dengan meniru gaya hewan tersebut, alhasil rata-rata siswa dengan presentase $95 \%$ lebih senang dan cenderung lebih faham apabila model tersebut di gunakan untuk media pembelajaran, sehingga siswa dapat aktif dalam melakukan proses belajar mengajar.

Setelah melakukan penelitian dengan rentang waktu 2 bulan tersebut dapat di simpulkan bahwasanya dengan menggunakan metode tersebut dapat meminimalisir waktu dan pemahaman siswa terhadap materi yang di sampaikan sangat memuaskan. Dari penelitian pada bulan pertama tedapat 10 siswa yang paham akan materi sedangkan pada bulan kedua meningkat drastis sebanyak $80 \%$ yang hasilnya 32 siswa telah memahami teknik shooting melalui metode discovery learning dengan menirukan gerakan nama-nama hewan tersebut.

Hal ini menandakan metode tersebut sangat cocok untuk bapak/ibu guru dalam memberikan materi bola basket baik kepada siswa SD, SMP atau bahkan di kalangan SMA.

\section{PENUTUP}

\section{Simpulan}

Dari hasil penelitian serta analisa dari Penelitian Tindakan Kelas Peserta didik SMA Ma'arif Ngawi yang telah dilakukan tentang peranan sarana dan prasarana serta proses belajar mengajar dengan penerapan discovery learning pada pembelajaran tersebut, maka dapat disimpulkan bahwa dalam proses belajar mengajar dengan menggunakan metode discovery learning sangat efektif sekali. Dapat di lihat dari hasil presentase keterampilan teknik shooting tersebut yang semula 25\% 
menjadi $80 \%$. Metode tersebut sangat cocok untuk bapak/ibu guru dalam meningkatkan khususnya tekink shooting dalam permainan bola basket. Karena selain meningkatkan keterampilan siswa dapat juga meminimalisir sarana dan prasarana yang ada, sehingga proses dalam kegiatan belajar mengajar dapat berjalan sebagaimana semestinya.

\section{Saran}

Hasil daripada pembahasan penelitian ini, maka adanya beberapa saran yang nantinya diharapkan dapat memberikan manfaat dari hasil penelitian ini sehingga dapat memberikan siswa kesempatan untuk dapat berfikir dan menemukan ide-ide yang kreatif. Adapun saran tersebut antara lain :

1) Untuk dapat membangkikan semangat dan kreatifitas siswa, agar di berikan sarana dan prasarana sebagaimana semestinya karena pentingnya sarana dan prasarana pembelajaran didalam untuk tercapainya suatu tujuan yang dihendaki oleh siswa / perserta didik.

2) Metode ini sangat cocok di gunakan apabila sarana dan prasarana yang sangat minim.

3) Sebagai tenaga pendidik terus berusaha untuk meningkatkan kemampuannya dalam mengembangkan materi, menyampaikan materi, serta dalam mengelola kelas, sehingga kualitas pembelajaran yang dilakukannya dapat terus meningkat seiring dengan peningkatan kemampuan yang dimilikinya.

4) Guru hendaknya lebih kreatif dalam menerapkan alat bantu pembelajaran untuk mempermudah peserta didik dalam menerima pembelajaran.

\section{DAFTAR PUSTAKA}

Irwandi(2015).Peranan Sarana dan Prasarana Terhadap Motivasi Belajar Pada Pembelajaran pendidikan Jasmani Olahraga dan Kesehatan di SMA Negeri 3 Banda Aceh. Peranan Sarana dan Prasarana, Motivasi Belajar. Volume II. Nomor 2, 5259

Firosalia Kristin(2016). Analisis Model Pembelajaran Dicovery Learning Dalam Meningkatkan Hasil Belajar Siswa SD. Discovery Learning, Hasil Belajar. Volume 2, Nomor 1, 90-97

Nurdin Muhamad(2016). Pengaruh Metode Discovery Learning Untuk Meningkatkan Representasi Matematis dan Percaya Diri Siswa. Metode Discovery Learning, Kemampuan Representasi Matematis, Percaya Diri. Vol. 09; No. 01, 9-14

Siti Mawaddah, Ratih Maryanti(2016).

Kemampuan Pemahaman Konsep

Matematis Siswa SMP Dalam

Pembelajaran Menggunakan Model

Penemuan Terbimbing (Dicovery

Learning). pembelajaran penemuan

terbimbing, kemampuan pemahaman

konsep, respon. Volume 4, Nomor 1, 7679

Harry Wibowo Sampurno, Wildan Qohhar(2020). Perbandingan Gaya

Mengajar Terhadap Hasil Shooting Bola Basket. Gaya Mengajar, Komando, Discoveri, Shooting Bola Basket. Volume 1 Nomor 2, 143-149

Fitrian Anggara Putra, Abdul Rachman Syam Tuasikal(2014). Penerapan Model Pembelajaran Aktif, Kreatif, dan Menyenangkan (PAKEM) Terhadap Hasil Belajar Shooting Bola Basket. Model Pembelajaran PAKEM, Shooting Bola Basket. Volume 02 Nomor 01, 283-285

Bachtiar S. Bachri(2010). Meyakinkan Validitas Data Melalui Triangulasi Pada Penelitian Kualitatif. Validitas Data, Paradigma Triangulasi, Penelitian Kualitatif. Vol. 10 No. 1, 46-52

Ellyza Sri Widyastuti(2015). Penerapan Model Pembelajaran Discovery Learning Pada 
Materi Konsep Ilmu Ekonomi. Discovery

Learning, Kesulitan Belajar. Prosiding

Seminar Nasional 9 Mei, 33-39

Hari Wibowo Sampurno, Suryadi(2020).

Perbandingan Gaya Mengajar Komando

Dengan Gaya Mengajar Diskoveri

Terhadap Hasil Belajar Menembak

(Shooting) Dalam Pembelajaran Bola

Basket. Gaya Mengajar, Komando,

Diskoveri, Shooting Bola Basket. Vol.9,

No.1, 71-77

Susanto Teguh. 2016. Buku Pintar Olah Raga.

Yogyakarta: Pustaka Baru Press.

Syarifudin.Sudrajat Wiradihardja. 2016.

Pendidikan Jasmani, Olah Raga, dan

Kesehatan. Jakarta: Pusat Kurikulum dan

Perbukuan, Balitbang, Kemendikbud. 